\title{
RECOVERING VALPARAÍSO'S URBAN ELEVATORS: THE RESTORATION OF THE CORDILLERA FUNICULAR
}

\author{
C. Giribas ${ }^{1}$, G. Paredes ${ }^{2}$, A. Riquelme ${ }^{3, *}$ \\ ${ }^{1}$ Escuela de Construcción en Tierra - EcoT, Santiago de Chile - camilogiribas@ gmail.com \\ ${ }^{2}$ Arquitecto Independiente, Inspector Fiscal Restauración Ascensor Cordillera, Valparaíso, Chile - guidoparedes@gmail.com \\ ${ }^{3}$ Xiloscopio Restauración y Conservación, Orrego 384, Cerro Esperanza, Valparaíso, Chile - arqlme@ gmail.com
}

\section{Commission II - WG II/8}

KEY WORDS: World Heritage, Valparaíso, Elevators, Restoration, Materials, Building system

\begin{abstract}
:
During the 19th century, the port of Valparaíso was the place in Chile with the closest links to the rest of the world, leading to strong social, cultural and technological transformations in the city. The arrival of the industrial revolution together with foreig $n$ influence led to the apparition of machinism; which along with the need to connect the lower area of the city with the hills led to the construction of several urban elevators. More than thirty elevators functioned throughout Valparaíso during the 20th century, out of which le ss than a half remained operational at the beginning of the 21 st century. In order to recover this valuable heritage in a city which was declared World Heritage in 2003 by UNESCO, the Ministry of Public Works of Chile promoted a plan to restore nine urban elevators in Valparaíso. This article refers specifically to the restoration works of the second elevator ever built in the city: the Cordillera funicu lar, which opened in 1887. The complexities linked to the recovery of an obsolete technological system for contemporary public transport standards will be exposed; along with relevant discoveries linked to the history of Valparaíso, such as the archaeological finding of the ruins of the San José Castle during building works.
\end{abstract}

\section{INTRODUCTION}

The restoration of the Cordillera elevator was carried out by the Chilean Ministry of Public Works between 2016 and 2018. Its original construction effectively represents the infrastructure that illustrates Valparaíso's historical, urban and social configuration from the 19th Century until today.

\section{HISTORY OF THE ELEVATORS}

\subsection{Brief history of Valparaíso}

The city of Valparaíso was first occupied in 1536. Growth during Spanish rule was slow and it was not until the second half of the 19th century, considered the golden age of Valparaíso, that it transformed from the rather small town it had once been into the thriving port city for which it is now known. This phenomenon played a vital role in developing Valparaiso's urban environment and the necessary conditions that allowed for the later construction of funiculars or elevators.

Demographic processes are widely considered as one of the engines of urban and population change. Valparaíso is a representative example of this, with a demographic growth that commenced in the 18th century and continued until the 19th century; during which some periods the growth was even explosive (Olivares, 2018; p 37). One of the causes of this was that in the middle of the 18th century, Valparaiso became the commercial and shipping center of the Pacific (Chapanoff, 2001), thanks to the export of wheat to California and Australia. This commercial exchange reached its peak in the middle of the 19th century (Sepúlveda, 2009).
The elimination of the Peñón de Cabo in 1832 coincided with this demographic growth and is partly due to it. For Sánchez and Jiménez (2011), this was the beginning of a process of defining the city's limits, consolidating the Almendral and Port sectors.

Four decades later, in 1876, the Mayor of Valparaíso, Francisco Echaurren, ratified this entire process of urban consolidation with the announcement of a "Valparaiso Transformation Plan". This strategy was focused on the lower, flat area of the city, currently known as the Plan, and seeked to improve its physiognomy through the use of urban equipment and the widening and cobbling of streets (Sepúlveda, 2009; p 39-40). Previous consolidation of the Plan and the construction of the camino cintura between 1886 and 1887 (an arterial road that connects the hills of Valparaiso at approximately 100 masl), led to the ultimate conquest and urbanization of the more elevated area of the city (Chapanoff, 2001).

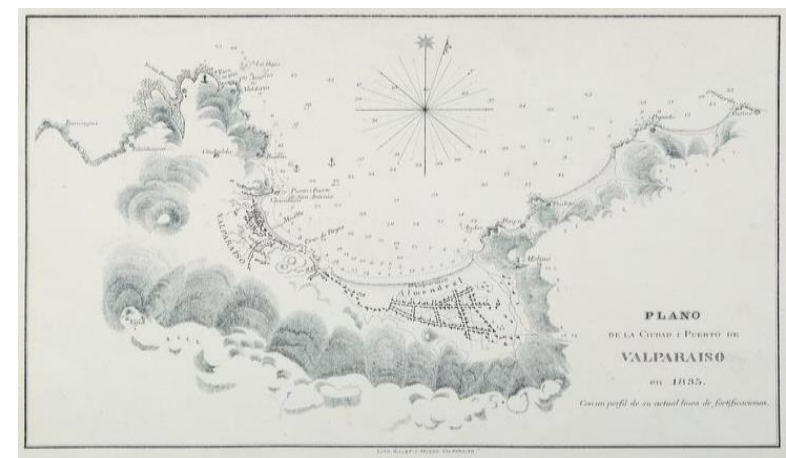

Figure 1. Valparaíso plan 1835. Mapoteca Archivo Nacional.

\footnotetext{
* Corresponding author
} 
All these processes, along with the reconfiguration of some sectors after the 1906 earthquake, indicate that the primary characteristic features of the Plan of Valparaíso, which are recognisable until our times, had already been determined by the middle of the 19th century (Rodríguez, Gajardo. 1906).

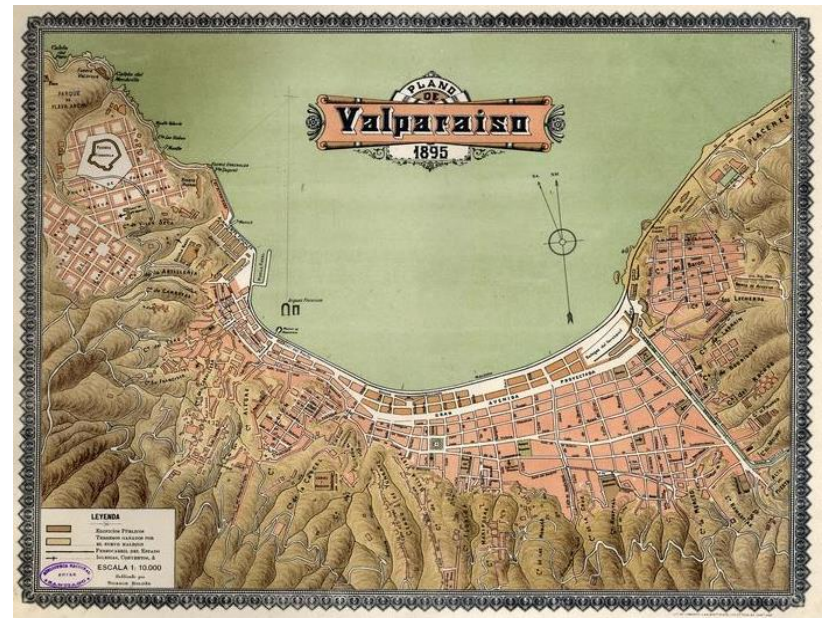

Figure 2. Valparaíso plan 1895. Nicanor Boloña: Álbum de planos de las principales ciudades y puertos de Chile.

\subsection{Urban development of the city and its influence on construction systems}

The oldest buildings that still stand in Valparaíso were built using a bearing system of adobe masonry walls. These structural walls were reinforced with pieces of wood above openings, in their corners and crownings. This system was inherited from colonial architecture and influenced local building systems until the end of the 19th century. A few well-known constructions built with this system are the churches of La Matriz (1559), San Francisco de Barón (1846) and the Chapel of Santa Ana (1881). Further evidence of this building system can be seen in countless homes throughout the city in which earthen bricks and wooden reinforcements are visible. The trouble with this system, however, is that it is vulnerable against seismic events due to deteriorating wooden elements that have suffered attacks from biological agents, ultimately weakening their structure and resistance.

During the 20th century, mainly after the earthquake that hit the central area of Chile in 1906, most buildings in Valparaíso were developed using mixed systems in which earthen materials were only used as an infill for other structures. One of the main techniques characteristic of this area is called adobillo, which consists of the infill of wooden structures with specially shaped earthen bricks. This change in the use of building systems was also triggered by the demographic growth of Valparaíso during that time. The growing population quickly occupied available space in the flat area of the city, making the El Almendral sector and the hills near the port the only available areas for urban growth (Duarte et al., 2007, sp.). Within these possibilities, technical innovation and alternative building solutions became necessary in order to make it possible to build on and ultimately occupy the hills. The use of thick adobe walls and heavy tiled roofs seemed particularly inappropriate for these areas since they required large foundation works (Duarte et al., 2007, sp.).

It is in this context that wood, with its versatility and efficient seismic behavior, was presented as an ideal solution for new constructions located on slopes. It was in these areas where this wooden framework system reached its maximum utility and application, and where bolder and more inventive building solutions were used to respond to the challenging topography. And it was this bold and inventive use of wood that gave rise to the most identifiable expressions of Valparaíso's urban morphology.

The lightness and speed of these constructions were significant advantages during construction, and they help explain the boom and subsequent proliferation of this building system particularly on the hills of Valparaíso. The application of this wooden building system quickly meant more effective and intense occupation of the upper part of the hills, consolidating this area of the city as we know it today (Duarte et al., 2007).

Valparaíso's widespread acceptance of this system is demonstrated in emblematic buildings of the time, such as the Baburizza Palace on the central hill of Cerro Alegre and the Vergara Palace, located in the center of the nearby town of Viña del Mar. Both of these palaces, built by wealthy families, ended up lengthening the list of Chilean National Monuments. In both examples the constructions' substrate was concealed under a superficial layer of stone masonry. While emblematic buildings of the time were built with burnt brick masonry walls which were reinforced with metal profiles, gypsum and cement plasters were used in these palaces to hide the wood and earthen structures. This shows that the application of these materials, which had been proven to resist seismic activity, was not only limited to the hills of Valparaíso. Although visual evidence of wooden building systems was not present, even opulent building owners employed this economical alternative in their constructions. It turned out that these wooden materials were more common than what met the eye.

\subsection{The construction of the elevators of Valparaíso}

Within this context, it is not surprising that in December of 1877 the Municipal Council discussed a project proposed by Isidoro Peirolux on building funiculars to connect the hills of Valparaíso. However, it was not until 1883, thanks to the work of the Valparaíso Mechanical Elevators Company, that the first of these elevators connected the Plan with Concepción Hill (León, 2015).

Álvarez (2016) stated that Valparaíso was the city of yesteryear with the most funiculars operating in the world. Elevators are a central part of the city's living social imaginary; of its construction as an idea, its intimacy with the landscape and its intense symbolic capital. Funiculars are, in a way, intensely glued to the city's skin. In spite of the picturesque quality that landscapes graced by funiculars have acquired with time, their origins are not aesthetic in nature.

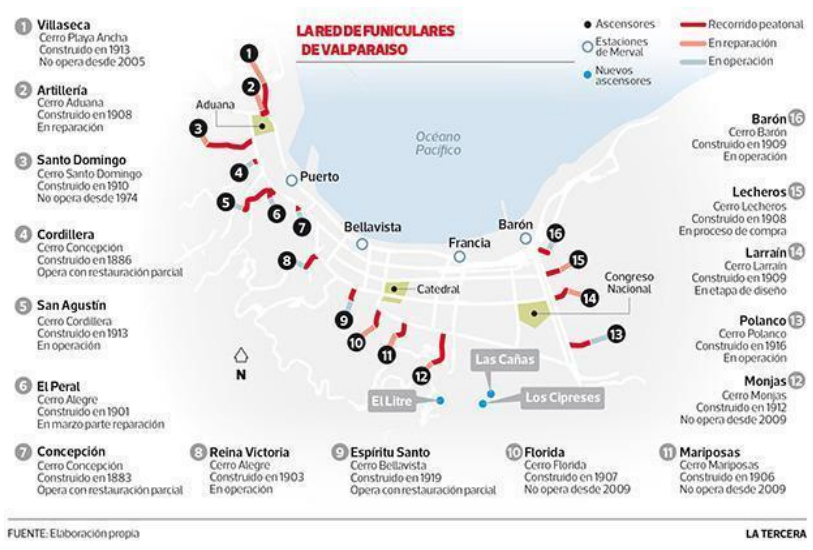

Figure 3. Valparaíso elevator plans. Source: Diario La Tercera. 
In this regard, Valparaíso's funiculars are valuable symbols of their time because they managed to effectively address the topographical discontinuity between the Plan and the hills to transform public transportation. Through the use of innovative technologies and the construction of funiculars, the transportation systems of the Plan and the hills were united to create a multimodal system.

It is necessary to emphasize that the implementation of elevators, or funiculars, in Chile, happened a few years after England's industrial production of braided steel cable and its ingenious electromechanical operating system- an important technological innovation for its time. This did nothing less than highlight Valparaíso as being on the cutting edge of new technologies during this time period (Migone, 2002).

The influence of the industrial revolution was enormous both in the proliferation of the use of wooden frames with adobillo infills and in the construction of elevators with mechanical pieces of steel such as pulleys, rails and winding drums. The era of machinism, with its full production armouries, allowed the development of an entire network of elevators, as well as the use of wood sizing machines that allowed and encouraged the construction of light frames (Balloon Frame). These, together with the adobillo earthen blocks, are part of the building culture that identifies Valparaíso as a World Heritage Site.

\section{THE 9 ELEVATORS RESTORATION PLAN}

In 2012, the Regional Government of Valparaíso purchased ten elevators, which had been previously declared historical monuments, from the Valparaíso Elevator Company. The Architecture Department of the Chilean Ministry of Public Works was in charge of this restoration process that included stages ranging from design under new safety operation standards and heritage restoration criteria, to construction. The Nine Elevator Restoration Plan of Valparaíso is currently being implemented.

\subsection{Context and situation of the elevators at the beginning of the 20th century}

Valparaíso's elevators represent an important part of Chilean industrial heritage. During the 19th century, the port of Valparaíso was Chile's greatest connection to other parts of the world, so it was strongly influenced by foreign countries.

This generated strong social, cultural and technological transformations. The industrial revolution brought the development of machinism, which, together with the need to connect the lower part of the port city with the hills that surrounded it, finally resulted in the construction of the elevators.

Since its reconstruction in 1894 , the Cordillera elevator has not stopped providing service as public transport connecting the Plan with Cordillera Hill. In 2008, it was one of the nine working elevators out of approximately thirty. This has not been the fate of other elevators, since over time, they have malfunctioned; in some cases, causing accidents. Of these accidents the first fatality was confirmed in 1903 after an incident at the Pantheon Elevator (León, 2015).

Apart from that, the thriving growth and prosperity boom that characterized Valparaíso since the middle of the 19th century began to gradually decline from the 1920's onwards. This was due to a series of international events, such as the opening of the Panama Canal in 1914; which slowly displaced the hegemony of Valparaíso as one of the main ports of the Pacific before crossing the Strait of Magellan.
In this way, as if reflecting the decline of Valparaíso, a process of gradual deterioration began that affected the elevators and the city as a whole. Two factors undermined the previous success and exclusivity of Valparaíso's elevators: the combination of the low maintenance of their electromechanical systems and the arrival of new types of public transport; such as shared taxis and urban micro-buses, to take passengers from the Plan to the hills. Elevators illustrated the city's response to the geography, spatial needs and technology of their time; but that was coming to an end.

Finally, in 1998 the Cordillera elevator, along with fourteen other funiculars, was declared a Historic Monument under the Decree No. 866 of 01.09.1998 of the Chilean Ministry of Education. This decree considered "that the elevators grant the city historical, social and touristic values, forming part of the characteristic appearance of the city" (CMN, 1998).

This declaration of the fourteen elevators as a historical monument was the beginning of the recognition of Valparaíso's historical heritage. In 2003, the historic center of the city, including Cordillera Hill and its elevator, was declared a UNESCO World Heritage Site.

With the aim of recovering and adapting safety standards in public transportation of the elevators that were in use, the Municipality of Valparaíso initiated concrete actions in 2008 which led to the complete restoration of the El Peral elevator. This elevator, which belonged to the Municipality, was the first to be restored entirely; namely its architecture, road plan and electromechanical system.

\subsection{Results to date}

Finally, in 2016, the bidding process to execute the restoration of the first three elevators began. They included Espíritu Santo, Concepción and Cordillera, which have already been completed. In the specific case of the Cordillera elevator, the restoration process lasted from December of 2016 to December of 2018, when, after two years, it was inaugurated on the 2nd of January of 2019.

\section{CORDILLERA ELEVATOR RESTORATION}

\subsection{History of the Cordillera elevator}

The second funicular ever built in Valparaíso was the Cordillera elevator, which was inaugurated on the 16th of September of 1886 , according to the original project carried out by the engineer F. von Collas in 1885 (León, 2015). On the 18th of March of 1894, the nearby Continental Hotel burnt down, destroying the elevator's facilities. Finally, it was rebuilt in its current location, and the Cienfuegos staircase was constructed parallel to the funicular's rolling plane. (León, 2015)

The lower station was located next to Sotomayor Square at 230 Serrano Street, and the upper station was located on Castillo Street near the exit of Plaza Eleuterio Ramírez on Cordillera Hill. The elevator made transport possible to a large number of Valparaíso's inhabitants. Many of them lived concentrated on this highly populated hill and earned their incomes working in port-related activities.

Between its lower and upper stations, the Cordillera elevator measures sixty meters long and fifty-five meters tall with a slope of seventy degrees. Its original water balance engine was replaced in 1910 by a steam engine. Until the intervention initiated by the Chilean Public Works Ministry in 2016, its motor was AEG - 575 volts - 45 amps of direct current with a winch made by W. T. Ellison's \& Co., (León, 2015). 


\subsection{Architecture and building systems}

The Cordillera elevator's architectural components include a lower station, the road plane and an upper station. The original programmatic design of the lower and upper stations considered that the elevator operators lived there. Therefore they were first defined as both public and residential buildings.

The upper station of the elevator has an approximate surface area of two hundred and fifty meters squared, and is constructed with foundations and overlays of stones and brick masonry, set on lime and sand mortars. Walls have partitions of American Oregon pine and oak measuring 4 x 4" and 3 x 4", filled with adobillos. The inner walls are coated with American Oregon pine boards and quincha: a system in which a fibre sub-structura is covered with earthen plasters. The outside is covered with small wave calamine. The roof is built with wooden trusses which hold a board that supports a layer of earth and small wave calamine planks as final coating.

The adobillo system consists of a structural wooden frame composed of vertical elements, or posts; horizontal elements, called upper and lower hearth, and bracing elements or diagonals. These are linked to each other using mortise and tenon joints, which make a firm skeleton which, together with other elements, form a resistant structure. Traditionally, the predominant wood used is oak, which has great resistance and a density of 0.67 gram per centimeter cubed. Mortises are located on hearths, and spikes on posts, allowing for the structure to stay in place during construction. Sometimes this system is reinforced with nails. The most commonly used of wood are quarters of 4 x 4 " and 3 x 4", which give enormous resistance to the entire system. The distance between posts range from forty to fifty $\mathrm{cm}$, which is determined by the dimension of adobillos placed between them (Riquelme; Cisterna, 2013).

Another vital element for the correct functioning of this system, which also determines the morphology of the adobillo, is the internal $1 \times 1$ " slat installed on both sides of each vertical post, covering its entire height. The wood used for this system is primarily oak for posts and poplar for slats. Each adobillo set between these wooden elements is designed with a groove that confines the slat, efficiently locking structure with its filling. This bond is part of the genesis of the adobillo, a prefabricated element which is only manufactured on site on blocks that are placed directly in contact with diagonals. In these cases, blocks have to be specially carved to fit into the structure. The most commonly found adobillo dimension in Valparaíso is $45 \mathrm{x} 10 \mathrm{x}$ $10 \mathrm{~cm}$.

Since the 19th century, the use of mixed systems has been a widely popular technique in Valparaíso, as well as other regions of the country. Over time, mixed systems have proved to provide durable structures to effectively address Chile's seismically active geography.

\subsection{Damage and restoration project}

The restoration project included the construction of a new lower station, the complete restoration of the railway (responsible for carrying passenger cars up and down), the construction of new cars, and the complete restoration of the upper station, which is the structure of the Cordillera elevator that maintains traditional building systems.

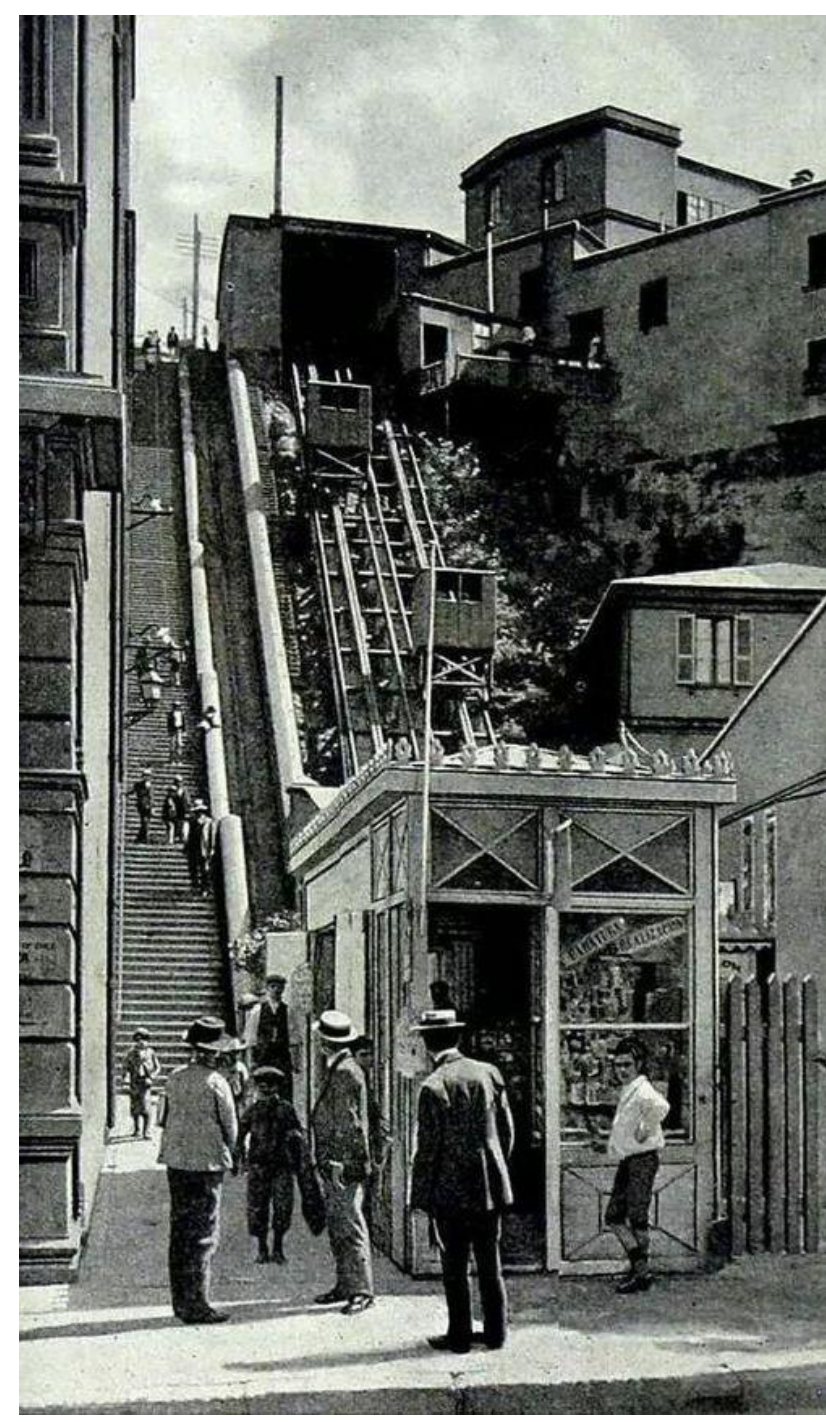

Figure 4. Cordillera elevator. 1910 approx.

Source: Historic Collection / Alamy Stock Photo

\section{RESTORATION MATERIALS AND CONSTRUCTION SYSTEMS}

\subsection{Masonry restoration}

The restoration project included structural consolidation of both the simple masonry elements present in the elevator and the foundations of the entire upper station, as well as the structure of the railway where the rails and ties were built.

On the railway, the original masonry was restored and a new structure of reinforced concrete was integrated on its back. This solution complies with Chilean regulations, since the construction of simple masonry is currently prohibited due to seismic requirements within the country.

The restoration of original masonry elements involved the removal of old stucco, reintegration of missing pieces and the introduction of new lime and sand mortars in empty or eroded areas. Finally, a water-proof finish was applied to protect the burnt bricks. 


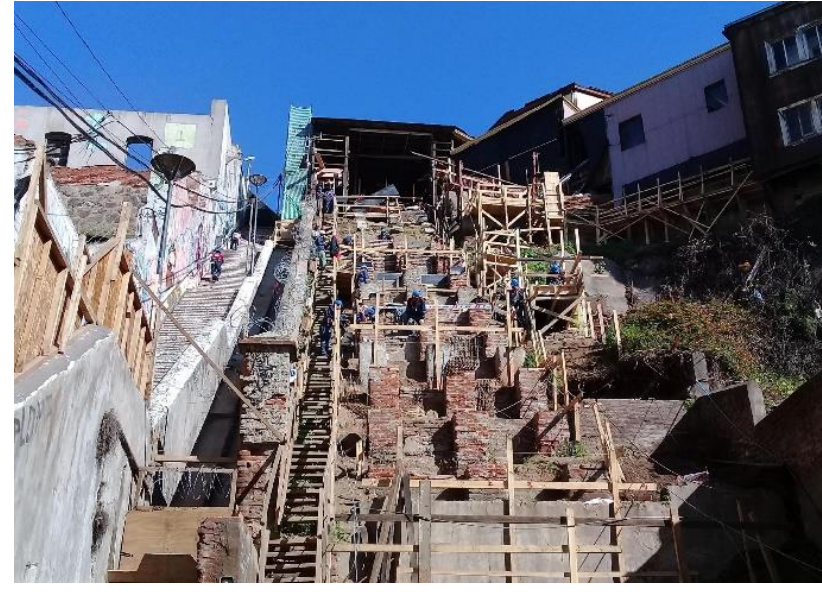

Figure 5. View of the railway at the Cordillera elevator.

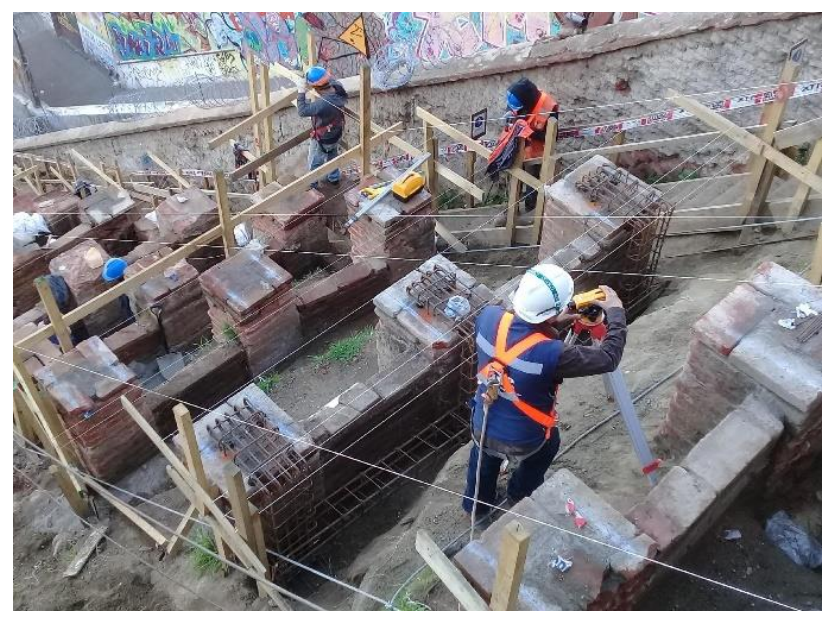

Figure 6 . View of the masonry and its reinforcements.

\subsection{Restoration of wooden elements}

The materials used to build the Cordillera elevator were mostly made of wood available in Valparaíso during the late 19th and early 20th centuries. In this period, native woods such as oak and coihue were used in structures; while laurel and raulí were found in non-structural elements and finishings. American Oregon pine was used indistinctly for coating, structures and typological elements. Each of these woods were used according to their stability, workability, aesthetics and, most importantly, availability.

To start the restoration process of non-structural wooden elements on the property, these elements were first observed and classified in their original positions. After this, the wooden elements were disassembled, packed and transferred to a specialised workshop. This procedure was modified for structural wood elements since their removal and dismantling was not feasible. Due to this, these elements were intervened on site.

The protocol developed for the restoration and conservation of non-structural elements established the following methodology:

5.2.1 Wood treatment: This process includes fumigation and healing wooden elements by using localised injections to fill perforations and hollow areas. Then, preventive treatment against xylophagous insects is carried out by impregnating wood with antixylophage protectors during the finishing stages.
5.2.2 Structural consolidation. Consolidation of the structure has the aim of stabilizing the different components and elements within it. To accomplish this, all loose or missing sections that compromise an element's capacity to support itself, including cracks and other degradations with a mechanical origin, have to be intervened. Consolidation of the Cordillera elevator was carried out by re-gluing all openings with PVA adhesive and applying pressure until each one closed. In some cases, some parts had to be rebuilt in order to complete the structure.

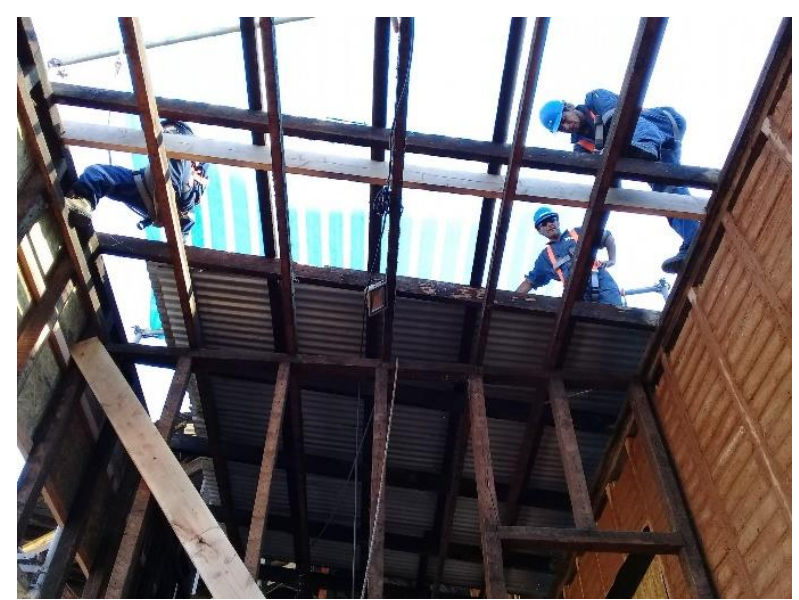

Figure 7. Structural consolidation of wooden beams.

5.2.3 Releases: According to the established restoration project, all layers of paint on each element had to be removed. Later insertions, such as wooden plates, nails, screws and other precarious materials that tried to hold the element together, were also removed.

5.2.4 Pickling: The pickling of elements was performed mechanically and chemically. The paint was first removed with heat guns and spatulas. Remnants of paint were then removed with paint remover. This action was only carried out to a certain extent, since when the natural patina of sealed wood started to appear behind the pictorial layers, pickling stopped and the wood and patina were preserved. Once this process was completed, the condition of the element could be observed again and suspected pathologies confirmed.

5.2.5 Wood integrations and reintegrations: Nonstructural elements were integrated and reintegrated. First, wood sections were reintegrated into elements that showed functional wear, which in the case of door stringers was due to hinges and locks. In lower combs, functional wear was associated with moisture, among other mechanical degradations and photo degradation in elements exposed to the sun. In cases where there was considerable material loss, pieces of wood were integrated according to the species and shape of each wooden element.

5.2.6 Finishes: Oil-based finishes were applied to protect the surface. There were two products used. The first finish was a translucent primer made of alkyd resin and solvent. This particular finish is microporous and allows wood to "breathe", therefore not causing breakage of protective film due to the intrinsic properties of the wood. The second product used was an oil-based finish. This lead-free finish, which does not flake or crack, is a natural and drying wax. Both products are compatible and, in the case of the Cordillera elevator, achieved both good protection and final appearance, preserving the aesthetic characteristics of the wood and resulting in a wood that is pleasant to the touch. 
In the case of metal objects, such as hinges and original plates (hardware), the existing paint on their surface was first removed to allow for later stabilization, which was carried out using acids. Tannic acid was used in the case of iron elements, while Rochelle salts were used for bronze, creating a protective coat of them. Finally, pieces were sealed with an epoxy film.

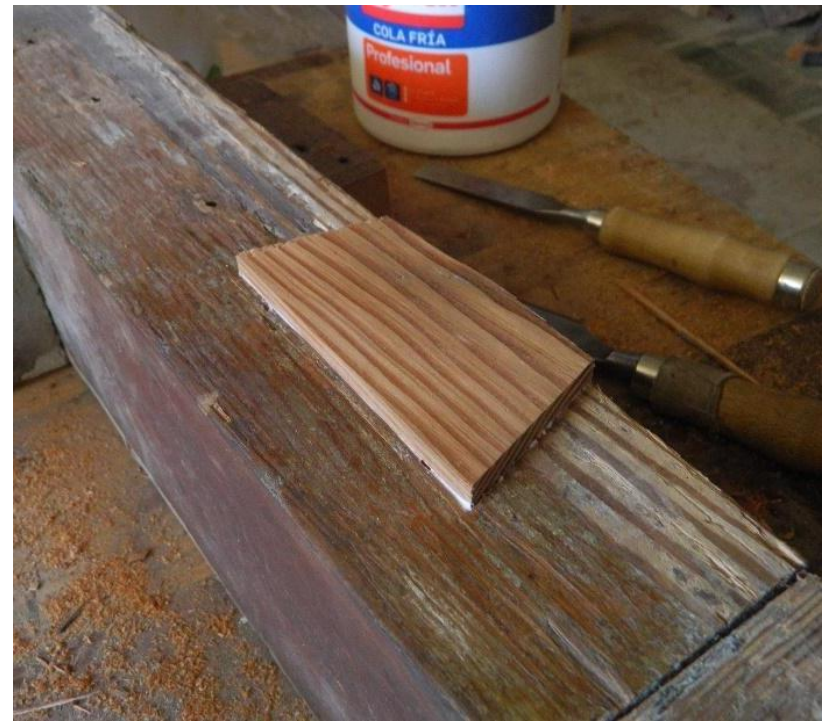

Figure 8. Integration in American Oregon pine.

\subsection{Restoration of adobillo}

Once the heritage value and the state of conservation of the structure in the upper station had been determined, the proposal for intervention was defined. In it, the mixed wood-earth construction system known as adobillo was recovered.

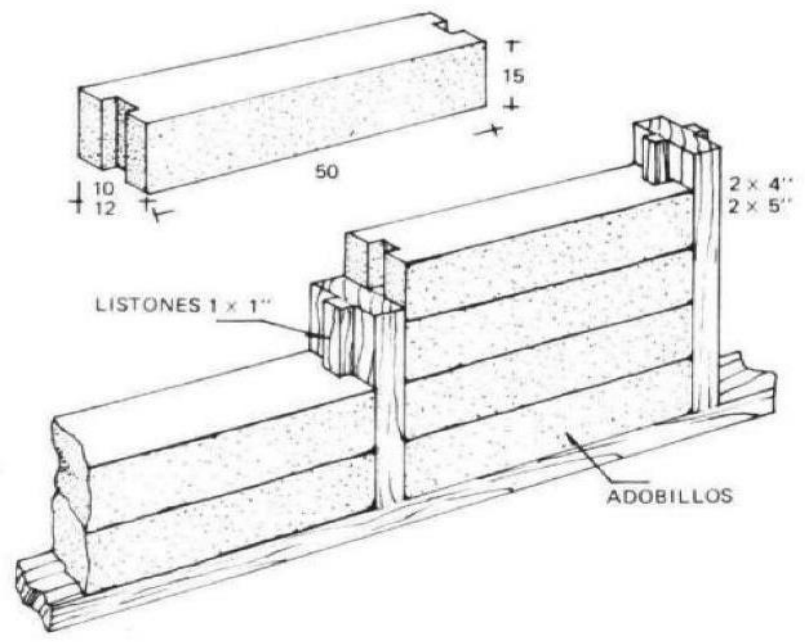

Figure 9. The adobillo building system. Source: Euclides Guzmán.

The following methodology was established with this system:

5.3.1 Emptying of structures: As a result of the diagnosis, adobillos between structures were removed. This was carried out through partial demolitions in order to generate spaces through which the blocks could be maneuvered and removed completely for later reuse. Broken pieces of removed blocks later served as mortar for new masonry.
5.3.2 Manufacturing mortar: The manufacturing of mortar was done by recycling the fragments of adobillos during the process of emptying structures. These fragments were ground and mixed with water in order to achieve a homogeneous paste that allowed the blocks to settle. Retraction of the mortar was controlled by adding one part coarse sand and 3\% of polyvinyl acetate of the added water volume.

5.3.3 Slat replacement: The integration of a $1 \times 1$ slat of impregnated pine wood was implemented to ensure fixing of earthen blocks. This element replaced old poplar ribbons which showed significant degradation both due to general rot and, in some specific sectors, the activity of xylophagous insects. Poplar wood has low levels of extractives, making it highly vulnerable to the appearance of xylophagous damage.

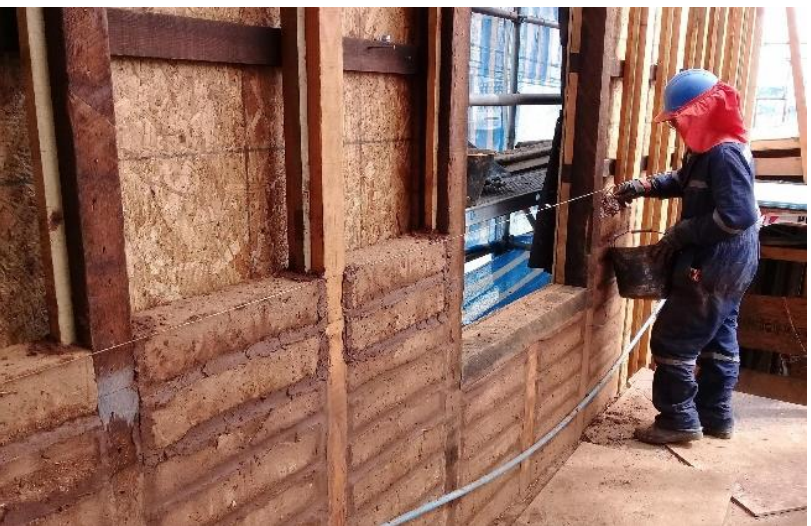

Figure 10. Installation of adobillo bricks.

\subsection{Metal restoration}

In regard to metallic elements with high patrimonial value, the turnstiles at the lower station of this elevator are particularly remarkable. These turnstiles are made of wrought iron and have movable blades which mechanically count users as they pass. In this sense, this is a functional element designed for passage and control of people. This system is one of the original assets of Valparaíso's centennial identity transport system and is considered utility furniture. The cast iron and bronze turnstile and its earthenware counter are part of the operation system of the elevator.

A comprehensive conservation and restoration project was developed for these pieces, in addition to generating a maintenance plan for their preservation.

In order to carry out the restoration of this element, a diagnosis of its conservation status was made, in which existing lesions and pathologies were defined. The tourniquet itself, which was in a medium state of preservation, had oxidized sections and an impact fracture in one of its pieces; which also showed an eccentric displacement in its operation, due to one of its broken blades.

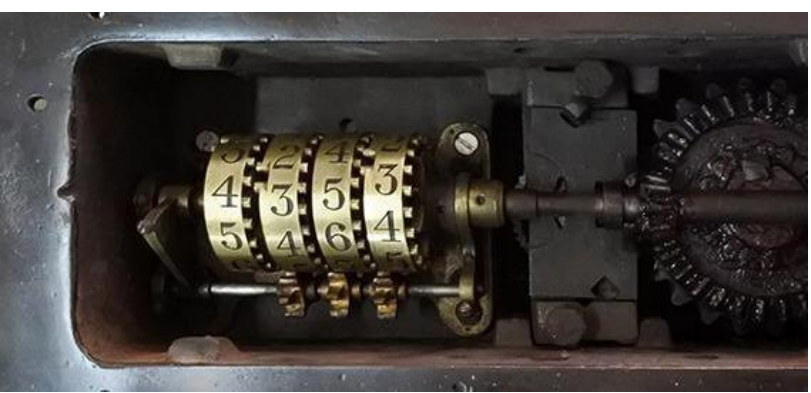

Figure 11. Cordillera elevator turnstile counter. 
Damage was mainly divided into two types: structural, related to fracture of materials and operation of blades, and aesthetic. The latter, consisting of the loss of paint layers and interventions associated with inappropriate maintenance and manipulation, made the adequate interpretation of the element difficult. First, the metal parts were cleaned, focusing on releasing damaging elements left behind from discordant interventions and existing chromatic films. A "dry" mechanical cleaning, and later, a chemical cleaning, were carried out in order to remove the aforementioned elements. After this, the broken piece was consolidated, welded and chromatically reintegrated to resemble the colour of the rest of the finishings. Oxidized parts were stabilised by the use of acids. Because of this, it was necessary to clean the piece again, this time with $2 \%$ active tensile, and then with the application and subsequent removal of 5\% oxalic acid. Finally, two coats of 5\% tannic acid were applied, the second of which generated a natural patina which was then coated with microcrystalline wax.

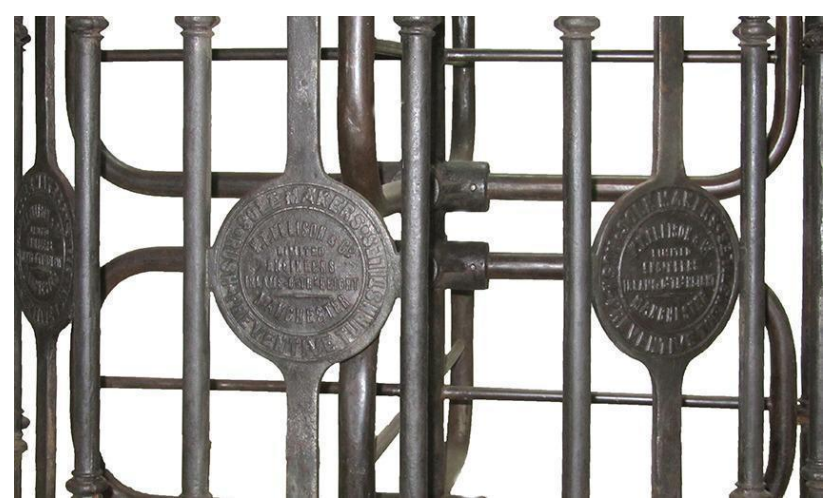

Figure 12. Turnstile blades of the Cordillera elevator. Source: Xiloscopio

\section{FINDINGS DURING THE WORK}

\subsection{The case of Castillo San José}

One of the significant events within the period of execution of the restoration work happened in 2017, when the floor of one of the precincts of the upper station was removed. Traces of an adobe wall were discovered under this floor. Further archaeological excavations uncovered a wall measuring over two meters high. Extending $130 \mathrm{~cm}$ up from the base, the wall was built with irregular stone masonry. Then, to increase the height by $20 \mathrm{~cm}$, two rows of burnt brick were laid on top. The upper part of the wall consisted of twelve rows of adobe blocks which reached a total height of $130 \mathrm{~cm}$, out of which the last adobe layers were the ones visible after the floor was removed.

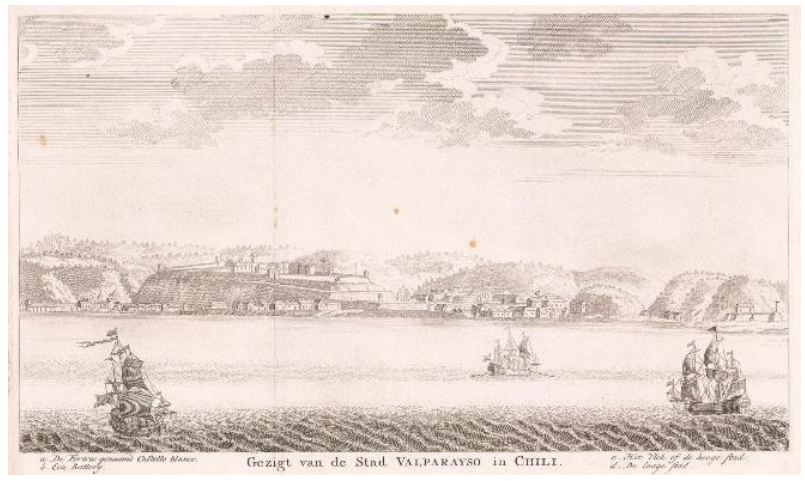

Figure 13. View of the bay of Valparaíso with Castillo San José in the background. Author: Isaak Tirion, 1766.
The wall is attributed to the remains of the San José Castle (Vanni, 2017), which was located on Cordillera Hill during the colonial period as part of the Spanish defence system against European privateers. The construction of this castle's fort ended in 1692 and, after independence, it was abandoned due to its continued deterioration until the 1822 earthquake left it in ruins. Finally, in 1840 the hill's land was subdivided and sold, leading the area to begin to acquire its current configuration $(\mathrm{CMN})$. This historical sequence makes this hypothesis on the wall's origin feasible.

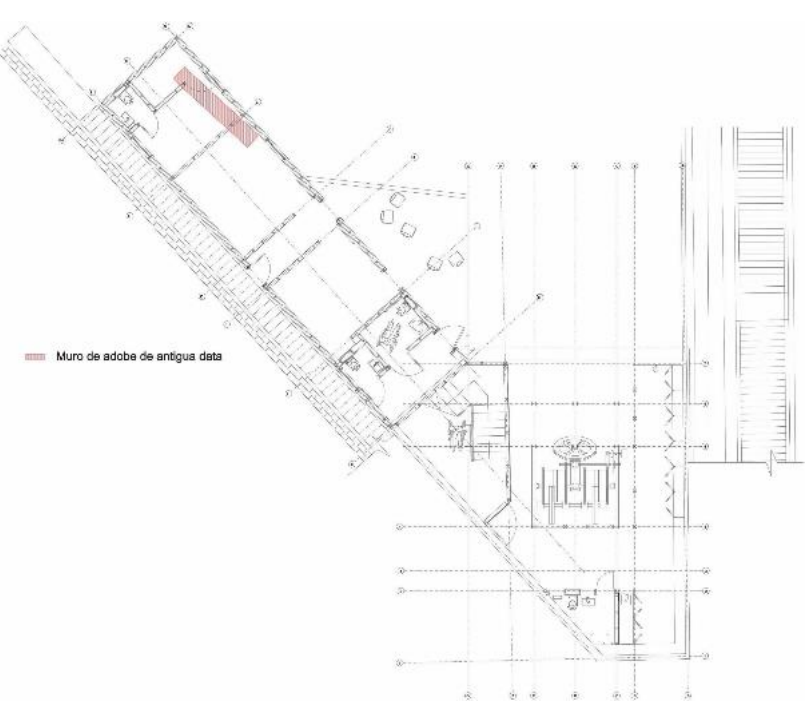

Figure 14. Plan of the upper station with the archaeological finding.

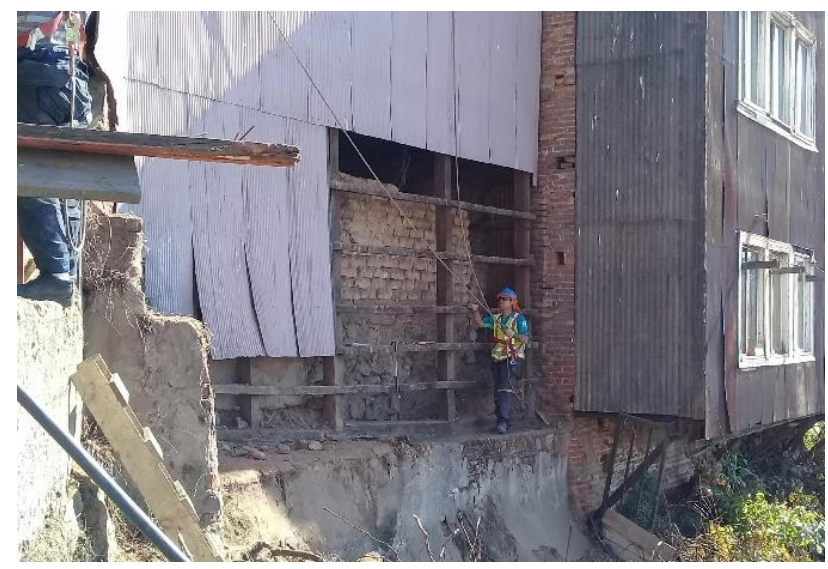

Figure 15. View of the wall discovered during restoration works.

\section{CONCLUSIONS}

The experience of the restoration of the Cordillera elevator, both from the private and public spheres, was an important opportunity to deepen knowledge in many disciplines. Insight was gained into the architecture, construction, history, archeology, electromechanics and traditional trades of Valparaíso elevators, all of which represent an important part of the built heritage of the city. The restoration works realized by the Chilean Ministry of Public Works helped normalize elevators as a means of certified public transport, incorporating safety conditions that improved the infrastructure of these ensembles for more than 100 years. 
After the declaration of Valparaíso as a UNESCO World Heritage Site, conservation of particular features linked to its origin became especially important. In the case of Valparaíso's elevators, maintaining their original function allows not only for a better tourist experience, but also sustains better mobility for the many permanent residents of Cordillera Hill, for who this 19th century infrastructure still remains useful today.

\section{REFERENCES}

Álvarez, L., Barría, C., 2016. Los 'ascensor' de primera generación como patrimonio industrial de Valparaíso, el caso del ascensor cordillera, la revolución del cable acerado (1850-1920), Informe Histórico Ascensor Cordillera.

Chapanoff, M., 2001. Del mundo correccional a la resignificación de lugar. Espacios de prisión en Valparaíso 1692-1940. Valparaíso: Ministerio de Bienes Nacionales - Chile.

Consejo de Monumentos Nacionales. Recuperado en https://www.monumentos.gob.cl/servicios/decretos/

Duarte, G., Patricio, H., Zúñiga, L., Isabel, M., 2007. Valparaíso cosmopolita: los efectos de la disposición a la técnica como parte de un espíritu progresista del siglo XIX. Revista de Urbanismo, No. 17, Universidad de Chile.

Guzmán, E., 1979. Curso elemental de edificación. Facultad de Arquitectura y Urbanismo de la Universidad de Chile. Editorial Universitaria.

Herrera, C., Jorge, Prieto, C., Virginia, 1964. La arquitectura de los ascensores urbanos de Valparaíso, Universidad de Chile, Sede Valparaíso, Escuela de Arquitectura.

León, S., 2008. Valparaíso sobre rieles. El ferrocarril, los tranvías y los 30 ascensores. Segunda Edición 2015, Biosférica Ediciones. Valparaíso. 2015.

Migone, J., 2002. Ascensores de Valparaíso: El Valor de un Patrimonio Olvidado, CONPAL. Seminario "Conservación del Patrimonio en América del Sur, Desafios y Soluciones". Sao Paulo, Brasil. 2002.

Migone, J., Pirozzi, A., 2001. Ascensores de Valparaíso. Valor de un patrimonio Olvidado. Santiago, Centro para la Conservación del Patrimonio Arquitectónico Latinoamericano. Delegación Chilena.

Olivares, N., 2018. Valparaíso. Estudio de poblamiento de sus quebradas y cerros, 1536 - 1900. Valparaíso: Ediciones Universitarias de Valparaíso.

Riquelme, A., Cisternas, V., 2013. La quincha interna, XIII SIACOT, Duoc UC, Valparaíso.

Rodríguez, A., Gajardo, C. 1906. La catástrofe del 16 de agosto de 1906 en la república de Chile. Santiago: Imprenta, litografía y encuadernación Barcelona.

Saelzer, G., 2014. Urbanismo topográfico según la cartografía histórica: desde las fortificaciones hasta las plazas de Valparaíso. Revista AUS, 15, pp 34-39.

Saelzer, G., 2017. Desde el urbanismo topográfico a las rectificaciones ilustradas: Ideario e instrucciones en Valparaíso, 1822-1895. Revista AUS, 21, pp 18-35.
Sánchez, A., Jiménez, C., 2011. Valparaíso: la ciudad-puerto más importante de Chile y la vulnerabilidad de su patrimonio arquitectónico a los riesgos sísmicos. Estudios Geográficos Vol. LXXII, 271, pp 559-589.

Sepúlveda, A., 2009. Plan de reconstrucción de Valparaíso 19061910: sus ideas urbanas hacia el centenario de la república. (Tesis de grado de Licenciatura en Historia). Universidad de Academia de Humanismo Cristiano, Santiago.

UNESCO, 2004. Postulación de Valparaíso como sitio de patrimonio mundial UNESCO. Cuadernos del Consejo de Monumentos Nacionales, segunda serie, №70.

Vanni, P., 2017. Encontraron muros del castillo del año 1696 en arreglos de Ascensor Cordillera. Recuperado de https://www.soychile.cl/Valparaíso/Sociedad/2017/05/27/46647 6/Encontraron-muros-de-castillo-del-ano-1696-en-arreglos-delAscensor-Cordillera.aspx 